\title{
Symptom prevalence and burden, and the risk of depression among patients with advanced cancer attending two South African oncology units
}

\author{
Lindsay Farrant ${ }^{1}$, Richard Harding ${ }^{2}$, David Anderson ${ }^{3}$, Linda Greeff ${ }^{4}$, Reshma Kassanjee 5 , R Krause ${ }^{1}$, Zainab Mohamed 6 , Jeannette Parkes ${ }^{6}$ \\ and Liz Gwyther ${ }^{1}$
}

\begin{abstract}
${ }^{1}$ Division of Interdisciplinary Palliative Care and Medicine, Department Public Health and Family Medicine, Faculty of Health Science, University of Cape Town, Anzio Road, Observatory 7925, Cape Town, South Africa

${ }^{2}$ Cicely Saunders Institute of Palliative Care, Policy and Rehabilitation, King's College London, Bessemer Road, London SE5 9PJ, UK

${ }^{3}$ Radiation Oncology, Dunedin Hospital, Southern DHB, 201 Great King Street, Dunedin 9016, New Zealand

${ }^{4}$ Social Worker in Private Practice, Andrag Street, Welgemoed 7530, Cape Town, South Africa

${ }^{5}$ Centre for Infectious Disease Epidemiology and Research (CIDER), Department Public Health and Family Medicine, University of Cape Town, Anzio Road, Observatory 7925, Cape Town, South Africa

${ }^{6}$ Division of Radiation Oncology, Department of Radiation Medicine, Faculty of Health Science, University of Cape Town, L-Block D-Floor, Room D-8, Groote Schuur Hospital, Observatory 7925, Cape Town, South Africa
\end{abstract}

\section{Abstract}

Background: The incidence of cancer is predicted to increase globally by $47 \%$ between 2020 and 2040, largely in low and middle-income countries. The World Health Organisation and World Health Assembly recognise palliative care as an essential component of cancer care. The evidence of palliative care needs among South African oncology patients is sparse. This study aimed to describe the prevalence and burden of symptoms and the risk of depression amongst oncology patients with stage 3 or 4 cancer.

Methods: Demographic and clinical data were collected and the Memorial Symptom Assessment Scale Short Form was used to measure the 7-day period prevalence of 28 physical and 4 psychological symptoms of patients receiving oncology care. The Centre for Epidemiological Studies Depression Scale was used to measure the risk of depression.

Results: A total of $N=343$ patients were recruited, of which $n=229$ (66.8\%) had stage 4 cancer. The mean number of symptoms was 11.56 (SD = 5.86). Pain and feeling drowsy/ tired were the two most prevalent symptoms. $N=66(19.3 \%)$ were at risk of mild depression and $n=27$ (7.9\%) for major depression.

Discussion: Pain and depression persist in advanced cancer care despite the advances in policy and clinical education. Health services research must now focus on how to enact this in routine practice.

Keywords: cancer, palliative care, symptoms, pain, depression

\section{Background}

The International Agency for Research on Cancer forecasts a $47 \%$ increase in new cancer cases globally between 2020 and 2040 [1]. Globocan (2020) predicts an 89\% increase in Africa for all cancer incidence by 2040 [2], with 1.34 million people dying of cancer in
Correspondence to: Lindsay Farrant Email: lindsay.farrant@uct.ac.za

ecancer 2022, 16:1349

https://doi.org/10.3332/ecancer.2022.1349

Published: $27 / 01 / 2022$

Received: 07/08/2021

Publication costs for this article were supported by ecancer (UK Charity number 1176307).

Copyright: (c) the authors; licensee ecancermedicalscience. This is an Open Access article distributed under the terms of the Creative Commons Attribution License (http:// creativecommons.org/licenses/by/4.0), which permits unrestricted use, distribution, and reproduction in any medium, provided the original work is properly cited. 
Africa between 2020 and 2040 [3]. The World Health Organisation's (WHO) 2018 mortality figures estimated 57,373 total cancer deaths in South Africa for that year [4]. During that year, 12,357 cancer patients were cared for by South African Hospices [5].

The projected increase in serious health-related suffering in the last year of life for people in low, lower-middle and upper-middle income countries will be largely driven by cancer $(407 \%, 168 \%$ and $96 \%$, respectively) $[6,7]$. The WHO articulates palliative care as an essential approach to cancer care that focuses on enhancing the quality of life for patients and families [8]. In 2014, the World Health Assembly (WHA) passed resolution 67.19, recognising palliative care as an essential component of care for all patients with life-threatening disease [9]. Palliative care is defined by the WHO as: 'an approach that improves the quality of life of patients and their families facing the problems associated with life-threatening illness, through the prevention and relief of suffering by means of early identification and impeccable assessment and treatment of pain and other problems, physical, psychosocial and spiritual' [10]. Meta-analyses of the available evidence has shown palliative care to be highly effective in improving outcomes for advanced cancer patients [11-13].

The characteristics of suffering that are unique to patients in a particular region should inform care planning and delivery. There is, however, very little evidence for the unique characteristics of suffering amongst patients with advanced cancer in South Africa. The point prevalence of public hospital inpatients with active life-limiting disease in 2011 was $16.6 \%, 50.8 \%$ of who had a cancer diagnosis [14]. Patients with advanced cancer in sub-Saharan Africa receiving formal palliative care report higher symptom prevalence and burden than those in the developed world [15]. There are no studies to date that report the symptom prevalence among advanced cancer patients who are not accessing formal palliative care. An earlier published systematic review comparing data on the prevalence of symptoms between advanced progressive conditions found no data on cancer patients in Africa [16], and a systematic review of care for patients with advanced disease in Africa found almost no evidence on the need or effectiveness of care [17]. Evidence from Africa is essential, as palliative care needs may be context-specific [18]. The symptom profile (in terms of prevalence and burden) of South Africans with advanced cancer who have not accessed palliative care is unclear. The existing evidence from South African patients who receive formal palliative care suggests a high prevalence of physical and psychological problems [15], a need for better spiritual care [19] and a need for information about symptoms and their control [20,21]. There is a body of evidence describing high prevalence of clinical depression in advanced disease [22] and the impact of depression on cancer progression in self-report physical outcomes, such as disability, pain and fatigue [23-25]. There is also a paucity of evidence for depression among cancer patients, although one South African study found that $36.6 \%$ of breast cancer patients (any stage) were at risk for depression [26]. The small body of existing evidence in Africa also includes cancer populations in West and East Africa [27-30]. In order to be able to provide 'feasible, acceptable and appropriate' $[15,17]$ palliative care to a growing number of patients, if the afore-mentioned predictions are accurate, we need data on the symptom prevalence and burden of patients with advanced cancer. No published study has aimed to determine the prevalence of depression, physical symptoms or quality of life in South Africans with advanced cancer.

Advances have been achieved in palliative care service provision in South Africa, which rely on a strong national network of accredited hospices, and the provision of medical and postgraduate education [31]. However, a systematic appraisal of the status of palliative care in sub-Saharan African countries found almost no evidence on the problems and outcomes of patients [17]. A study conducted at a hospitalbased outreach palliative care service, in Soweto, found that hospital costs may be reduced by reducing the number of hospital admissions for those patients cared for by the palliative care service and that such services 'may improve quality of life' of the patients [32]. Our study aimed to measure the 7-day period prevalence and associated burden of physical and psychological symptoms among adults attending oncology clinics with stage 3 or 4 disease in the metropolitan Western Cape of South Africa, and to measure the risk of depression.

\section{Methodology}

The primary sites were a public tertiary oncology unit and a private oncology unit. The study population included adult patients (aged 18 years or older) who had a diagnosis of cancer of stage 3 or 4 (or poor risk in the case of Kaposi sarcoma), attending both the inpatient and outpatient oncology services and who were able to consent to partake in the study. The eight primary cancer groups were selected from 2008 GLOBOCAN tables on age standardised incidence and mortality rates and local unpublished patient incidence data: breast, prostate, oesophageal, lung, cervical, colorectal, head and neck cancers and Kaposi's sarcoma [33]. Recruitment tables of primary cancer were used in an effort to match samples between the two sites. We aimed for a total sample of 400 participants to measure the prevalence of any 
symptom with $95 \%$ confidence and 5\% margin of error, proportionally stratified by primary malignancy using local (unpublished) data. Consecutive convenience sampling (December 2013 to March 2016) was applied. We excluded patients who were under 18 years old, unaware of their diagnosis, lacked capacity (either physical or mental) to give informed consent and complete a 45-minute interview.

As healthcare is becoming more responsive to patient accounts of their disease [34], patient reported outcome measures or 'PROMS' have become increasingly important in improving care and ensuring equity [35]. We selected measures with sound psychometric properties that have been previously used in South Africa. All tools, information and consent forms were forward and backward translated from English into the principle languages of isiXhosa and Afrikaans. All data were patient self-report. In order to reduce measurement and response bias, all questions were read aloud and patients gave their responses to be recorded by the trained researcher. The following patient demographics were collected: age, gender, public or private care, education and socio-economic status. The following disease-oriented variables were collected: primary cancer site, metastases, disease stage, human immunodeficiency virus status, current and previous treatment for the cancer and admissions in the prior 12 months. We also recorded place of care (inpatient or outpatient). The Eastern Co-operative Oncology Group Performance Scale (ECOG, 1 item) [36] was administered to measure physical performance. The Memorial Symptom Assessment Scale Shortform (MSAS-SF, 32 items) [37] was administered to measure the 7-day period prevalence and associated burden of multidimensional symptoms. The MSAS-SF offers three subscale indices of Physical Symptom Distress Index (MSAS-PHYS), Psychological Symptom Distress Index (MSAS-PSYCH) and Global Distress Index (MSAS-GDI). Each of these three subscales has a possible score range of 0-4. This well-validated multidimensional instrument captures the presence and distress of 28 physical and 4 psychological symptoms among cancer patients. The MSAS is one of the most widely used symptom tools in oncology, and we have previously applied it in multicentre research in South Africa [15]. The Centre for Epidemiological Studies on Depression (CES-D, 20 items) [38] was used as a screening scale measuring feelings and behaviours characteristic of symptoms of depression during the past week. The scores ranged from 0 to 60 , and $16+$ used as a cut-off for probable caseness [38]. It has been used in previous community depression studies in South Africa [39-41]. It has a Cronbach's alpha value of 0.90 for women and 0.91 for men. None of the items in the selected measures mention palliative or terminal care, and therefore did not risk sharing information with patients that might not have been previously communicated by their clinician. The study was approved by the University of Cape Town's Human Research Ethics Committee: HREC Ref No: 287/2012.

Sample characteristics were summarised descriptively. The CES-D scores were calculated and stratified according to the three-level cut-off, as proposed by Zich et al [42]. The MSAS-SF symptom prevalence and burden, as well as MSAS-SF subscales and total number of symptoms, were calculated. Analyses were conducted using Statistical Package for the Social Sciences Statistics (version 26).

\section{Results}

\section{Sample characteristics}

A total of $N=343$ participants were recruited, with $n=48(14 \%)$ in the private sector and $n=295(86 \%)$ in the public sector. The majority were outpatients $(n=247,72 \%)$. There were $n=201$ (58.6\%) female participants. The mean age of the participants was 58.4 years (SD 13.1). Ninety-three participants (27.1\%) had completed primary school education, 205 (59.8\%) had completed a secondary school education and 41 (12\%) had a higher qualification. Ninety-five (27.7\%) participants were receiving chemotherapy at the time of study and $n=56$ (16.3\%) were receiving radiotherapy, whilst $n=185$ (53.9\%) had previously received chemotherapy and $n=170$ (49.6\%) radiotherapy. The majority ( $n=229,66.8 \%$ ) had been staged as 4 . Table 1 details the primary malignancy diagnoses for participants. $N=20$ participants were recruited with primary malignancies other than these 8 groups and were included in the overall analysis.

\section{Measures}

The median score for the ECOG functional status was 2 (SD = 1.09). Forty-nine (14.3\%) participants were fully functional (i.e., ECOG score $=0$ ), $29.7 \%$ had an ECOG 1 score, 31.2\% had an ECOG 2 score, 19.2\% had an ECOG 3 score and 5.5\% were completely disabled with an ECOG 4 score. 
Table 1. Primary malignancy $(n=343)$.

\begin{tabular}{|l|c|c|}
\hline \multicolumn{1}{|c|}{ Primary cancer } & Frequency & Percent (\%) \\
\hline Lung cancer & 87 & 25.4 \\
\hline Breast cancer & 87 & 25.4 \\
\hline Colorectal cancer & 60 & 17.5 \\
\hline Head and neck tumours & 29 & 8.5 \\
\hline Prostate cancer & 23 & 6.7 \\
\hline Cervical cancer & 15 & 4.4 \\
\hline Cancer of the oesophagus & 12 & 3.5 \\
\hline Kaposi Sarcomas & 10 & 2.9 \\
\hline Other & 20 & 5.8 \\
\hline
\end{tabular}

The 7-day period prevalence of symptoms and burden as per the MSAS-SF is detailed in Table 2. The mean number of symptoms was 11.56 $(S D=5.86)$. The ten most prevalent symptoms were pain (64.7\%), feeling drowsy/tired (64.7\%), lack of energy (62.4\%), dry mouth (53.4\%), worrying (51.3\%), shortness of breath (50.1\%), cough (48.1\%), feeling sad (42.9\%), changes in skin (42.9\%) and difficulty sleeping (42.0\%).

For participants reporting pain, $47.3 \%$ reported that their pain distressed them on the two worst response levels, i.e., 'quite a bit' or 'very much'. Worry was the most prevalent psychological symptom, with $30.7 \%$ of the participants reporting worrying 'frequently' or 'almost constantly'. Difficulty sleeping was reported by 144 (42.0\%) participants and was the most burdensome symptom reported, with $61.7 \%$ of the participants with the symptom, reporting that this symptom distressed them 'quite a bit' or 'very much'. Table 2 presents the 7-day period prevalence and burden of symptoms.

MSAS-SF subscales were as follows: MSAS-GDI was 1.23 (SD = 0.88), MSAS-PHYS was 1.09 (SD = 0.83), and MSAS-PSYCH was 0.91 $(\mathrm{SD}=0.87)$.

According to the three-level cut-off of the CES-D $(n=342), n=249(72.8 \%)$ participants had no risk of depression, $n=66(19.3 \%)$ participants were at risk for mild depression and $n=27$ (7.9\%) participants were at risk for major depression.

Table 2. The 7-day period prevalence of symptoms and burden by MSAS-SF.

\begin{tabular}{|c|c|c|c|c|c|c|}
\hline \multicolumn{7}{|c|}{ 7-day period prevalence of symptoms and burden $(n=343)$} \\
\hline \multirow[b]{2}{*}{ Physical symptoms } & \multirow[b]{2}{*}{ Prevalence $\mathrm{N}(\%)$} & \multicolumn{5}{|c|}{ Burden of prevalent symptoms, $n(\%)^{\text {a }}$} \\
\hline & & Not at all (1) & A little bit (2) & Somewhat (3) & Quite a bit (4) & Very much (5) \\
\hline Pain & $\begin{array}{c}222 \\
(64.7 \%) \\
\text { (missing } n=1)\end{array}$ & $\begin{array}{c}11 \\
(5.0 \%)\end{array}$ & $\begin{array}{c}67 \\
(30.2 \%)\end{array}$ & $\begin{array}{c}39 \\
(17.6 \%)\end{array}$ & $\begin{array}{c}38 \\
(17.1 \%)\end{array}$ & $\begin{array}{c}67 \\
(30.2 \%)\end{array}$ \\
\hline Feeling drowsy/tired & $\begin{array}{c}222 \\
(64.7 \%)\end{array}$ & $\begin{array}{c}28 \\
(12.6 \%)\end{array}$ & $\begin{array}{c}54 \\
(24.3 \%)\end{array}$ & $\begin{array}{c}38 \\
(17.1 \%)\end{array}$ & $\begin{array}{c}37 \\
(16.7 \%)\end{array}$ & $\begin{array}{c}65 \\
(29.3 \%)\end{array}$ \\
\hline Lack of energy & $\begin{array}{c}214 \\
(62.4 \%)\end{array}$ & $\begin{array}{c}21 \\
(9.8 \%)\end{array}$ & $\begin{array}{c}55 \\
(2.6 \%)\end{array}$ & $\begin{array}{c}41 \\
(19.2 \%)\end{array}$ & $\begin{array}{c}42 \\
(19.6 \%)\end{array}$ & $\begin{array}{c}55 \\
(25.7 \%)\end{array}$ \\
\hline Dry mouth & $\begin{array}{c}183 \\
(53.4 \%)\end{array}$ & $\begin{array}{c}31 \\
(16.9 \%)\end{array}$ & $\begin{array}{c}41 \\
(22.4 \%)\end{array}$ & $\begin{array}{c}21 \\
(11.5 \%)\end{array}$ & $\begin{array}{c}37 \\
(20.2 \%)\end{array}$ & $\begin{array}{c}53 \\
(28.9 \%)\end{array}$ \\
\hline Shortness of breath & $\begin{array}{c}172 \\
(50.1 \%)\end{array}$ & $\begin{array}{c}20 \\
(11.6 \%)\end{array}$ & $\begin{array}{c}47 \\
(27.3 \%)\end{array}$ & $\begin{array}{c}24 \\
(13.9 \%)\end{array}$ & $\begin{array}{c}29 \\
(16.9 \%)\end{array}$ & $\begin{array}{c}52 \\
(30.2 \%)\end{array}$ \\
\hline
\end{tabular}


Table 2. The 7-day period prevalence of symptoms and burden by MSAS-SF. (Continued)

\begin{tabular}{|c|c|c|c|c|c|c|}
\hline Cough & $\begin{array}{c}165 \\
(48.1 \%)\end{array}$ & $\begin{array}{c}29 \\
(17.6 \%)\end{array}$ & $\begin{array}{c}48 \\
(29.1 \%)\end{array}$ & $\begin{array}{c}18 \\
(10.9 \%)\end{array}$ & $\begin{array}{c}24 \\
(14.5 \%)\end{array}$ & $\begin{array}{c}45 \\
(27.3 \%)\end{array}$ \\
\hline Changes in skin & $\begin{array}{c}147 \\
(42.9 \%)\end{array}$ & $\begin{array}{c}56 \\
(38.1 \%)\end{array}$ & $\begin{array}{c}29 \\
(19.7 \%)\end{array}$ & $\begin{array}{c}14 \\
(9.5 \%)\end{array}$ & $\begin{array}{c}18 \\
(12.2 \%)\end{array}$ & $\begin{array}{c}30 \\
(20.4 \%)\end{array}$ \\
\hline Difficulty sleeping & $\begin{array}{c}144 \\
(42.0 \%)\end{array}$ & $\begin{array}{c}16 \\
(11.1 \%)\end{array}$ & $\begin{array}{c}22 \\
(15.3 \%)\end{array}$ & $\begin{array}{c}17 \\
(11.8 \%)\end{array}$ & $\begin{array}{c}31 \\
(21.5 \%)\end{array}$ & $\begin{array}{c}58 \\
(40.2 \%)\end{array}$ \\
\hline Constipation & $\begin{array}{c}141 \\
(41.1 \%)\end{array}$ & $\begin{array}{c}22 \\
(15.6 \%)\end{array}$ & $\begin{array}{c}32 \\
(22.7 \%)\end{array}$ & $\begin{array}{c}20 \\
(14.2 \%)\end{array}$ & $\begin{array}{c}26 \\
(18.4 \%)\end{array}$ & $\begin{array}{c}41 \\
(29.1 \%)\end{array}$ \\
\hline Sweats & $\begin{array}{c}141 \\
(41.1 \%)\end{array}$ & $\begin{array}{c}33 \\
(23.4 \%)\end{array}$ & $\begin{array}{c}41 \\
(29.1 \%) \\
\end{array}$ & $\begin{array}{c}12 \\
(8.5 \%)\end{array}$ & $\begin{array}{c}20 \\
(14.2 \%)\end{array}$ & $\begin{array}{c}35 \\
(24.8 \%) \\
\end{array}$ \\
\hline $\begin{array}{l}\text { Numbness/tingling in hands } \\
\text { or feet }\end{array}$ & $\begin{array}{c}136 \\
(39.7 \%)\end{array}$ & $\begin{array}{c}27 \\
(19.9 \%)\end{array}$ & $\begin{array}{c}32 \\
(23.5 \%)\end{array}$ & $\begin{array}{c}33 \\
(24.3 \%)\end{array}$ & $\begin{array}{c}18 \\
(13.2 \%)\end{array}$ & $\begin{array}{c}26 \\
(19.1 \%)\end{array}$ \\
\hline Lack of appetite & $\begin{array}{c}136 \\
(39.7 \%)\end{array}$ & $\begin{array}{c}20 \\
(14.7 \%)\end{array}$ & $\begin{array}{c}28 \\
(20.6 \%)\end{array}$ & $\begin{array}{c}18 \\
(13.2 \%)\end{array}$ & $\begin{array}{c}25 \\
(18.4 \%)\end{array}$ & $\begin{array}{c}45 \\
(33.1 \%)\end{array}$ \\
\hline Nausea & $\begin{array}{c}133 \\
(38.8 \%)\end{array}$ & $\begin{array}{c}15 \\
(11.3 \%)\end{array}$ & $\begin{array}{c}41 \\
(30.8 \%)\end{array}$ & $\begin{array}{c}24 \\
(18.0 \%)\end{array}$ & $\begin{array}{c}21 \\
(15.8 \%)\end{array}$ & $\begin{array}{c}32 \\
(24.1 \%)\end{array}$ \\
\hline Changes in way food tastes & $\begin{array}{c}125 \\
(36.4 \%)\end{array}$ & $\begin{array}{c}29 \\
(23.2 \%)\end{array}$ & $\begin{array}{c}26 \\
(20.8 \%)\end{array}$ & $\begin{array}{c}19 \\
(15.2 \%)\end{array}$ & $\begin{array}{c}27 \\
(21.6 \%)\end{array}$ & $\begin{array}{c}24 \\
(19.2 \%)\end{array}$ \\
\hline Weight loss & $\begin{array}{c}119 \\
(34.7 \%)\end{array}$ & $\begin{array}{c}41 \\
(34.5 \%)\end{array}$ & $\begin{array}{c}15 \\
(12.6 \%)\end{array}$ & $\begin{array}{c}3 \\
(2.5 \%)\end{array}$ & $\begin{array}{c}29 \\
(24.4 \%)\end{array}$ & $\begin{array}{c}32 \\
(26.9 \%)\end{array}$ \\
\hline I don't look like myself & $\begin{array}{c}119 \\
(34.7 \%)\end{array}$ & $\begin{array}{c}40 \\
(33.6 \%)\end{array}$ & $\begin{array}{c}25 \\
(21.0 \%)\end{array}$ & $\begin{array}{c}11 \\
(9.2 \%)\end{array}$ & $\begin{array}{c}22 \\
(18.5 \%)\end{array}$ & $\begin{array}{c}21 \\
(17.6 \%)\end{array}$ \\
\hline Dizziness & $\begin{array}{c}119 \\
(34.7 \%)\end{array}$ & $\begin{array}{c}16 \\
(13.4 \%)\end{array}$ & $\begin{array}{c}33 \\
(27.7 \%)\end{array}$ & $\begin{array}{c}34 \\
(28.6 \%)\end{array}$ & $\begin{array}{c}10 \\
(8.4 \%)\end{array}$ & $\begin{array}{c}26 \\
(21.8 \%)\end{array}$ \\
\hline Feeling bloated & $\begin{array}{c}93 \\
(27.1 \%)\end{array}$ & $\begin{array}{c}14 \\
(15.1 \%)\end{array}$ & $\begin{array}{c}21 \\
(22.6 \%)\end{array}$ & $\begin{array}{c}11 \\
(11.8 \%)\end{array}$ & $\begin{array}{c}24 \\
(25.8 \%)\end{array}$ & $\begin{array}{c}22 \\
(23.7 \%)\end{array}$ \\
\hline Itching & $\begin{array}{c}84 \\
(24.5 \%)\end{array}$ & $\begin{array}{c}19 \\
(22.6 \%)\end{array}$ & $\begin{array}{c}23 \\
(27.4 \%)\end{array}$ & $\begin{array}{c}9 \\
(10.7 \%)\end{array}$ & $\begin{array}{c}8 \\
(9.5 \%)\end{array}$ & $\begin{array}{c}24 \\
(28.6 \%)\end{array}$ \\
\hline Swelling of arms or legs & $\begin{array}{c}80 \\
(23.3 \%)\end{array}$ & $\begin{array}{c}26 \\
(32.5 \%)\end{array}$ & $\begin{array}{c}17 \\
(21.3 \%)\end{array}$ & $\begin{array}{c}8 \\
(10.0 \%)\end{array}$ & $\begin{array}{c}8 \\
(10.0 \%)\end{array}$ & $\begin{array}{c}23 \\
(28.8 \%)\end{array}$ \\
\hline Difficulty concentrating & $\begin{array}{c}78 \\
(22.7 \%)\end{array}$ & 12 (15.3\%) & $\begin{array}{c}21 \\
(26.9 \%)\end{array}$ & $\begin{array}{c}22 \\
(28.2 \%)\end{array}$ & $\begin{array}{c}12 \\
(15.3 \%)\end{array}$ & $\begin{array}{c}12 \\
(15.3 \%)\end{array}$ \\
\hline Difficulty swallowing & $\begin{array}{c}70 \\
(20.4 \%)\end{array}$ & $\begin{array}{c}1 \\
(1.4 \%)\end{array}$ & $\begin{array}{c}21 \\
(30.0 \%)\end{array}$ & $\begin{array}{c}9 \\
(12.9 \%)\end{array}$ & $\begin{array}{c}15 \\
(21.4 \%)\end{array}$ & $\begin{array}{c}24 \\
(34.3 \%)\end{array}$ \\
\hline Vomiting & $\begin{array}{c}64 \\
(18.7 \%)\end{array}$ & $\begin{array}{c}12 \\
(18.8 \%)\end{array}$ & $\begin{array}{c}23 \\
(35.9 \%)\end{array}$ & $\begin{array}{c}4 \\
(6.3 \%)\end{array}$ & $\begin{array}{c}14 \\
(21.9 \%)\end{array}$ & $\begin{array}{c}11 \\
(17.2 \%)\end{array}$ \\
\hline Diarrhoea & $\begin{array}{c}51 \\
(14.9 \%)\end{array}$ & $\begin{array}{c}10 \\
(19.6 \%)\end{array}$ & $\begin{array}{c}18 \\
(35.3 \%)\end{array}$ & $\begin{array}{c}8 \\
(15.7 \%)\end{array}$ & $\begin{array}{c}2 \\
(3.9 \%)\end{array}$ & $\begin{array}{c}13 \\
(25.5 \%)\end{array}$ \\
\hline $\begin{array}{l}\text { Problems with sexual } \\
\text { interest/activity }\end{array}$ & $\begin{array}{c}50 \\
(14.6 \%) \\
\end{array}$ & $\begin{array}{c}12 \\
(24.0 \%)\end{array}$ & $\begin{array}{c}8 \\
(16.0 \%) \\
\end{array}$ & $\begin{array}{c}3 \\
(6.0 \%) \\
\end{array}$ & $\begin{array}{c}3 \\
(6.0 \%) \\
\end{array}$ & $\begin{array}{c}24 \\
(48.0 \%) \\
\end{array}$ \\
\hline Mouth sores & $\begin{array}{c}45 \\
(13.1 \%)\end{array}$ & $\begin{array}{c}7 \\
(15.6 \%)\end{array}$ & $\begin{array}{c}16 \\
(35.6 \%)\end{array}$ & $\begin{array}{c}9 \\
(20.0 \%)\end{array}$ & $\begin{array}{c}8 \\
(17.8 \%)\end{array}$ & $\begin{array}{c}5 \\
(11.1 \%)\end{array}$ \\
\hline
\end{tabular}


Table 2. The 7-day period prevalence of symptoms and burden by MSAS-SF. (Continued)

\begin{tabular}{|c|c|c|c|c|c|c|}
\hline Hair loss & $\begin{array}{c}36 \\
(10.5 \%)\end{array}$ & $\begin{array}{c}19 \\
(52.8 \%)\end{array}$ & $\begin{array}{c}8 \\
(22.2 \%)\end{array}$ & $\begin{array}{c}1 \\
(2.8 \%)\end{array}$ & $\begin{array}{c}3 \\
(8.3 \%)\end{array}$ & $\begin{array}{c}7 \\
(19.4 \%)\end{array}$ \\
\hline Problems urinating & $\begin{array}{c}35 \\
(10.2 \%)\end{array}$ & $\begin{array}{c}7 \\
(20.0 \%)\end{array}$ & $\begin{array}{c}7 \\
(20.0 \%)\end{array}$ & $\begin{array}{c}3 \\
(8.6 \%)\end{array}$ & $\begin{array}{c}6 \\
(17.1 \%)\end{array}$ & $\begin{array}{c}12 \\
(34.3 \%)\end{array}$ \\
\hline Psychological symptoms & Prevalence & $\begin{array}{l}\text { Rarely } \\
\text { (1) }\end{array}$ & $\begin{array}{l}\text { Occasionally } \\
\text { (2) }\end{array}$ & $\begin{array}{l}\text { Frequently } \\
\text { (3) }\end{array}$ & $\begin{array}{l}\text { Almost constantly } \\
\text { (4) }\end{array}$ & \\
\hline Worrying & $\begin{array}{c}176 \\
(51.3 \%)\end{array}$ & $\begin{array}{c}47 \\
(26.7 \%)\end{array}$ & $\begin{array}{c}75 \\
(42.6 \%)\end{array}$ & $\begin{array}{c}26 \\
(14.8 \%)\end{array}$ & $\begin{array}{c}28 \\
(15.9 \%)\end{array}$ & \\
\hline Feeling sad & $\begin{array}{c}147 \\
(42.9 \%) \\
\end{array}$ & $\begin{array}{c}57 \\
(38.8 \%) \\
\end{array}$ & $\begin{array}{c}56 \\
(38.1 \%) \\
\end{array}$ & $\begin{array}{c}20 \\
(13.6 \%) \\
\end{array}$ & $\begin{array}{c}14 \\
(9.5 \%)\end{array}$ & \\
\hline Feeling nervous & $\begin{array}{c}142 \\
(41.4 \%) \\
\end{array}$ & $\begin{array}{c}42 \\
(29.6 \%) \\
\end{array}$ & $\begin{array}{c}46 \\
(32.4 \%) \\
\end{array}$ & $\begin{array}{c}34 \\
(23.9 \%) \\
\end{array}$ & $\begin{array}{c}19 \\
(13.4 \%) \\
\end{array}$ & \\
\hline Feeling irritable & $\begin{array}{c}133 \\
(38.8 \%)\end{array}$ & $\begin{array}{c}35 \\
(26.3 \%)\end{array}$ & $\begin{array}{c}52 \\
(39.1 \%)\end{array}$ & $\begin{array}{c}27 \\
(20.3 \%)\end{array}$ & $\begin{array}{c}18 \\
(13.5 \%)\end{array}$ & \\
\hline
\end{tabular}

a Do not add up to $100 \%$ due to rounding.

\section{Discussion}

These data present symptom prevalence and burden and the risk of depression (measured by CES-D) amongst patients with advanced cancer who were receiving care in oncology clinics. Standard care in both private and public sectors included standard oncology care. Palliative care training had not yet been integrated into oncology registrar training and so although standard oncology care would have included some aspects of palliative care, this would not routinely have included integrated palliative care.

The mean number of symptoms experienced by patients in our study is similar to those of international studies, including studies in other African countries [43-48]. However, the study conducted by Harding et al [15] on patients with cancer receiving palliative care in Uganda and South Africa found a mean number of 18 symptoms and higher mean MSAS-SF subscale indices than in our study. It is possible that patients with more than the average number of symptoms, or with more advanced disease, are more readily referred to a palliative care service.

Studies report varying prevalence of pain, from $41 \%$ in a study of Chinese cancer patients [45] to $87 \%$ in a study of patients with cancer receiving palliative care in Uganda and South Africa [15, 43, 44, 47-49] with a systematic review reporting a prevalence of at least $50 \%$ in cancer patients. The prevalence of pain in our study was $64.7 \%$, with $47.1 \%$ of patients with pain describing the burden as high (rated as 'quite a bit' or 'very much'), emphasising the importance of regular pain assessment and management as part of oncology care patients with stage 3 and 4 cancer. Feeling tired/drowsy, lack of energy and dry mouth were highly prevalent symptoms with a burden of over $45 \%$ each, and are similar to the findings in other studies of advanced cancer patients [15, 44]. While it may be difficult to palliate these symptoms, their impact on quality of life should be explored holistically by the interdisciplinary team. Shortness of breath and cough were reported by around half the patients, similar to the study in Uganda and South Africa, [15] but the associated burden of $47.1 \%$ reporting that shortness of breath bothered them 'quite a bit' or 'very much' is higher than in the Uganda/South Africa study [15].

Psychological symptoms were prevalent amongst this group, with worrying as the most commonly reported psychological symptom (51.3\%), and $30.7 \%$ of participants with this symptom reporting high distress (rated at 'frequently' or 'almost constantly'). The prevalence of all four of the psychological symptoms in our study is similar to the findings by Hwang et al [44], however, is lower than reported in the study by Harding et al [15]. The symptom distress is similar for feeling sad and worrying; however, our study reports higher distress from feeling nervous or feeling irritable [15]. What appears to be clear is that psychological symptoms and distress are common in patients with stage 3 and 4 cancer and it is important to screen for this distress. There is some evidence that the prevalence of depression in the general population of South Africa is similar to, or perhaps somewhat higher than, that reported from developing countries [50-52]. Just over a quarter of our sample were at risk for depression, with $7.9 \%$ being at risk for major depression. This finding correlates with international literature on the 
risk for depression amongst patients with advanced cancer [44, 22]. Similarly, Kagee et al [26] reported one-third of South African breast cancer patients were at risk for depression, of which half had stage 2 disease. Pirl et al [53] found that treatment of depression in patients with recently diagnosed metastatic non-small cell lung cancer did improve their depression. This data regarding the high risk for depression amongst oncology patients in South Africa, together with evidence of the benefit of prompt treatment of depression, is a call to ensure adequate and regular screening and access to treatment and support for patients with advanced cancer who have depression or experience other psychological distress.

There are a number of limitations of this study. We were unable to reach the intended target sample size due to recruitment being limited to the funding available. We were unable to report a response rate because the study was introduced to participants by a variety of clinicians and the recording of accurate response rates in a busy clinic setting was challenging.

\section{Conclusion}

These findings show that there is a high physical and psychological symptom burden and distress among advanced cancer patients and associated risk for depression. The international evidence for the benefit of the integration of a palliative care approach into oncology care for patients with advanced cancer is clear [11-13]. The findings verify the need to incorporate palliative care training into oncology programmes. The National Policy Framework and Strategy on Palliative Care 2017-2022 provides the platform for the necessary integration to occur [54], but resource allocation has been very limited. There is an urgent need to harness available resources for interdisciplinary teamwork between trained and equipped healthcare professionals, alongside the need for research into how to provide integrated 'feasible, acceptable and appropriate' palliative care $[15,17]$ for patients receiving care in oncology clinics. This includes the need for collaboration with mental health services for the holistic care of patients with depression. Our data demonstrate persisting high prevalence and burden of symptoms, despite enabling policy and clinical education. Mechanisms must be developed and evaluated to assist clinicians in incorporating palliative care into oncology practice.

\section{Authors' contributions}

LF wrote and all authors reviewed and commented on the manuscript. RH and LG conceived the study. RH, LG and LF wrote the study proposal with input from JP, DA, LGreeff. LF conducted statistical analysis with guidance from RK.

\section{Conflicts of interests}

The authors declare that they have no competing interests.

\section{Funding}

Funding for this study was from AORTIC and NIH in the form of a BIG CAT II award.

\section{References}

1. Sung H, Ferlay J, and Siegel RL, et al (2021) Global cancer statistics 2020: GLOBOCAN estimates of incidence and mortality worldwide for 36 cancers in 185 countries CA Cancer J Clin 71(3) 209-249 https://doi.org/10.3322/caac.21660 PMID: 33538338

2. Union for International Cancer Control (2020) GLOBOCAN: Cancer Tomorrow: Estimated Number of New Cases from 2020 to 2040 (Lyon: International Agency for Research on Cancer) [https://gco.iarc.fr/tomorrow/en/dataviz/bars?mode=population] 
3. Union for International Cancer Control (2020) GLOBOCAN: Cancer Tomorrow: Estimated Number of Deaths from 2020 to 2040 (Lyon: International Agency for Research on Cancer) [https://gco.iarc.fr/tomorrow/en/dataviz/isotype?populations= 12_24_72_108_120_132_140_148_174_178_180_204_226_231_232_262_266_270_288_324_384_404_426_430_434_450_454_4 66_478_480_504_508_516_562_566_624_638_646_678_686_694_706_710_716_728_729_748_768_788_800_818_834_854_894 \&group_populations=1\&multiple_populations=1\&single_unit=50000\&types $=1]$

4. World Health Organisation (2020) South Africa: Cancer Country Profile 2020 (Geneva: World Health Organisation) [https://www.who.int/ cancer/country-profiles/ZAF_2020.pdf?ua=1]

5. Hospice Palliative Care Association of South Africa (2020) HPCA Annual Report 2020 [https://hpca.co.za/Resources/annual-report/.

6. Sleeman KE, de Brito M, and Etkind S, et al (2019) The escalating global burden of serious health-related suffering: projections to 2060 by world regions, age groups, and health conditions Lancet Glob Health 7(7) e883-e92 https://doi.org/10.1016/S2214-109X(19)30172-X PMID: 31129125 PMCID: 6560023

7. Sleeman KE, Gomes B, and de Brito M, et al (2021) The burden of serious health-related suffering among cancer decedents: global projections study to 2060 Palliat Med 35(1) 231-235 https://doi.org/10.1177/0269216320957561 PMCID: 7797611

8. World Health Organisation (2021) Cancer: Palliative Care [https://www.who.int/cancer/palliative/en/] Date accessed: [Cited 26/05/21]

9. Executive Board 134 (2014) Strengthening of Palliative Care as a Component of Integrated Treatment Within the Continuum of Care [https:// apps.who.int/iris/handle/10665/173012] (Geneva: World Health Assembly)

10. Sepúlveda C, Marlin A, and Yoshida T, et al (2002) Palliative care: the World Health Organisation's perspective JPSM 24(2) 91-96

11. Gaertner J, Siemens W, and Meerpohl JJ, et al (2017) Effect of specialist palliative care services on quality of life in adults with advanced incurable illness in hospital, hospice, or community settings: systematic review and meta-analysis BMJ $357 \mathrm{j} 2925$ https://doi. org/10.1136/bmj.j2925 PMID: 28676557 PMCID: 5496011

12. Higginson IJ and Evans $\mathrm{CJ}$ (2010) What is the evidence that palliative care teams improve outcomes for cancer patients and their families? Cancer J 16(5) 423-435 https://doi.org/10.1097/PPO.0b013e3181f684e5 PMID: 20890138

13. Seow H, Brazil K, and Sussman J, et al (2014) Impact of community based, specialist palliative care teams on hospitalisations and emergency department visits late in life and hospital deaths: a pooled analysis BMJ 348 g3496 https://doi.org/10.1136/bmj.g3496 PMID: 24906901 PMCID: 4048125

14. van Niekerk $L$ and Raubenheimer PJ (2014) A point-prevalence survey of public hospital inpatients with palliative care needs in Cape Town, South Africa S Afr Med J 104(2) 138-141 https://doi.org/10.7196/samj.7262 PMID: 24893546

15. Harding R, Selman L, and Agupio G, et al (2011) The prevalence and burden of symptoms amongst cancer patients attending palliative care in two African countries Eur J Cancer 47(1) 51-56 https://doi.org/10.1016/j.ejca.2010.08.003

16. Solano JP, Gomes B, and Higginson IJ (2006) A comparison of symptom prevalence in far advanced cancer, AIDS, heart disease, chronic obstructive pulmonary disease and renal disease J Pain Symptom Manage 31(1) 58-69 https://doi.org/10.1016/j.jpainsym$\underline{\text { man.2005.06.007 PMID: } 16442483}$

17. Harding R and Higginson IJ (2005) Palliative care in sub-Saharan Africa Lancet 365(9475) 1971-1977 https://doi.org/10.1016/S01406736(05)66666-4 PMID: 15936427

18. Afolabi OA, Nkhoma K, and Maddocks M, et al (2021) What constitutes a palliative care need in people with serious illnesses across Africa? A mixed-methods systematic review of the concept and evidence Palliat Med 2692163211008784

19. Selman LE, Higginson IJ, and Agupio G, et al (2011) Quality of life among patients receiving palliative care in South Africa and Uganda: a multi-centred study Health Qual Life Outcomes 921 https://doi.org/10.1186/1477-7525-9-21 PMID: 21477274 PMCID: 3094195 
20. Murray SA, Grant E, and Grant A, et al (2003) Dying from cancer in developed and developing countries: lessons from two qualitative interview studies of patients and their carers BMJ 326(7385) 368 https://doi.org/10.1136/bmj.326.7385.368 PMID: 12586671 PMCID: 148895

21. Selman L, Higginson IJ, and Agupio G, et al (2009) Meeting information needs of patients with incurable progressive disease and their families in South Africa and Uganda: multicentre qualitative study BMJ 338 b1326 https://doi.org/10.1136/bmj.b1326 PMID: 19386672 PMCID: 3273778

22. Hotopf MCJ, Addington-Hall J, and Ly KL (2002) Depression in advanced disease: a systematic review Part 1. Prevalence and case finding Palliat Med 16(2) 81-97 PMID: 11969152

23. Hotopf MMR, Wadsworth M, and Wessely S (1998) Temporal relationships between physical symptoms and psychiatric disorder. Results from a national birth cohort Br J Psychiatry 173 255-261 https://doi.org/10.1192/bjp.173.3.255

24. Wells KB SA, Hays RD, and Burman MA, et al (1989) The functioning and well-being of depressed patients. Results from the medical outcomes study JAMA 262(7) 914-919 https://doi.org/10.1001/jama.1989.03430070062031 PMID: 2754791

25. Barkwell D (1991) Ascribed meaning a critical factor in coping and pain attenuation in patients with cancer-related pain $J$ Palliat Care 7(3) 5-14 https://doi.org/10.1177/082585979100700302 PMID: 1941361

26. Kagee A, Roomaney R, and Knoll N (2018) Psychosocial predictors of distress and depression among South African breast cancer patients Psychooncology 27(3) 908-914 https://doi.org/10.1002/pon.4589

27. Boulaamane L, Essaadi I, and Lalya I, et al (2011) [Psychosocial impact of cancer on Moroccan adolescent and young adult: experience of National Institute of Oncology of Rabat] Bull Cancer 98(9) 981-988 https://doi.org/10.1684/bdc.2011.1427 PMID: 21896399

28. Olagunju AT and Aina OF (2011) A controlled study of depression among attendees of an oncology clinic in West Africa Int J Psychiatry Med 42(4) 339-352 https://doi.org/10.2190/PM.42.4.a PMID: 22530397

29. Clegg-Lamptey JNA, Dakubo JCB, and Attobra YN (2009) Psychosocial aspects of breast cancer treatment in Accra, Ghana East Afr Med J 86(7) 348-353

30. Nuhu FT, Odejide O, and Adebayo KO, et al (2009) Psychological and physical effects of pain on cancer patients in Ibadan, Nigeria Afr J Psychiatry 12(1) 64-70 https://doi.org/10.4314/ajpsy.v12i1.30281

31. Ens C, Chochinov HM, and Gwyther L, et al (2011) Postgraduate palliative care education: Evaluation of a South African programme S Afr Med J 101 42-44 https://doi.org/10.7196/SAMJ.4171 PMID: 21626981

32. Hongoro $C$ and Dinat N (2011) A cost analysis of a hospital-based palliative care outreach program: implications for expanding public sector palliative care in South Africa J Pain Symptom Manage 41(6) 1015-1024 https://doi.org/10.1016/j.jpainsymman.2010.08.014 PMID: 21330096

33. Union for International Cancer Control (2008) GLOBOCAN: Cancer Mortality Data South African Republic 2008

34. Giusti A, Nkhoma K, and Petrus R, et al (2020) The empirical evidence underpinning the concept and practice of person-centred care for serious illness: a systematic review BMJ Glob Health 5(12) https://doi.org/10.1136/bmjgh-2020-003330 PMID: 33303515 PMCID: 7733074

35. Dawson J, Doll H, and Fitzpatrick R, et al (2010) The routine use of patient reported outcome measures in healthcare settings BMJ 340 c186 https://doi.org/10.1136/bmj.c186 PMID: 20083546

36. Oken MM, Creech RH, and Tormey DC, et al (1982) Toxicity and response criteria of the Eastern Cooperative Oncology Group Am J Clin Oncol 5 649-655 https://doi.org/10.1097/00000421-198212000-00014 PMID: 7165009

37. Chang VT, Hwang SS, and Feuerman M, et al (2000) The memorial symptom assessment scale short form (MSAS-SF) Cancer 89(5) 1162-1171 https://doi.org/10.1002/1097-0142(20000901)89:5<1162::AID-CNCR26>3.0.CO;2-Y PMID: 10964347 
38. Radloff LS (1977) The CES-D scale: A self-report depression scale for research in the general population Appl Psychol Measure 1(3) 385-401 https://doi.org/10.1177/014662167700100306

39. Nduna M, Jewkes RK, and Dunkle KL, et al (2010) Associations between depressive symptoms, sexual behaviour and relationship characteristics: a prospective cohort study of young women and men in the Eastern Cape, South Africa J Int AIDS Soc 1344 https://doi. org/10.1186/1758-2652-13-44 PMID: 21078150 PMCID: 2992477

40. Hutton HE, Lyketsos CG, and Zenilman JM, et al (2004) Depression and HIV risk behaviors among patients in a sexually transmitted disease clinic Am J Psychiatry 161(5) 912-914 https://doi.org/10.1176/appi.ajp.161.5.912 PMID: 15121659

41. Kaminer D, Grimsrud A, and Myer L, et al (2008) Risk for post-traumatic stress disorder associated with different forms of interpersonal violence in South Africa Soc Sci Med 67(10) 1589-1595 https://doi.org/10.1016/j.socscimed.2008.07.023 PMID: 18774211 PMCID: $\underline{2610682}$

42. Zich JM, Attkisson CC, and Greenfield TK (1990) Screening for depression in primary care clinics: the CES-D and the BDI Int J Psychiatry Med 20(3) 259-277 https://doi.org/10.2190/LYKR-7VHP-YJEM-MKM2 PMID: 2265888

43. Tranmer JE, Heyland D, and Dudgeon D, et al (2003) Measuring the symptom experience of seriously III cancer and noncancer hospitalized patients near the end of life with the Memorial Symptom Assessment Scale J Pain Symptom Manag 25(5) 420-429 https://doi. org/10.1016/S0885-3924(03)00074-5

44. Hwang SS, Chang VT, and Cogswell J, et al (2004) Study of unmet needs in symptomatic veterans with advanced cancer: incidence, independent predictors and unmet needs outcome model J Pain Symptom Manage 28(5) 421-432 https://doi.org/10.1016/j.jpainsymman.2004.02.023 PMID: 15504619

45. Lam WW, Law CC, and Fu YT, et al (2008) New insights in symptom assessment: the Chinese Versions of the Memorial Symptom Assessment Scale Short Form (MSAS-SF) and the Condensed MSAS (CMSAS) J Pain Symptom Manage 36(6) 584-595 https://doi. org/10.1016/j.jpainsymman.2007.12.008 PMID: 18434076

46. Bekelman DB, Rumsfeld JS, and Havranek EP, et al (2009) Symptom burden, depression, and spiritual well-being: a comparison of heart failure and advanced cancer patients J Gen Intern Med 24(5) 592-598 https://doi.org/10.1007/s11606-009-0931-y PMID: 19288160 PMCID: 2669863

47. Lazenby M, Sebego M, and Swart NC, et al (2016) Symptom burden and functional dependencies among cancer patients in Botswana suggest a need for palliative care nursing Cancer Nurs 39(1) E29-E38 https://doi.org/10.1097/NCC.0000000000000249

48. Isiaka-Lawal SA (2017) An Exploration of Symptom Burden among Breast and Gynaecological Cancer Patients Accessing Care at University of Ilorin Teaching Hospital, llorin, Kwara State, Nigeria [Masters Dissertation] (Cape Town : University of Cape Town)

49. Breivik H, Cherny N, and Collett B, et al (2009) Cancer-related pain: a pan-European survey of prevalence, treatment, and patient attitudes Ann Oncol 20(8) 1420-1433 https://doi.org/10.1093/annonc/mdp001 PMID: 19244085

50. Myer L, Stein DJ, and Grimsrud A, et al (2008) Social determinants of psychological distress in a nationally-representative sample of South African adults Soc Sci Med 66(8) 1828-1840 https://doi.org/10.1016/j.socscimed.2008.01.025 PMID: 18299167 PMCID: 3203636

51. Tomlinson M, Swartz L, and Kruger LM, et al (2007) Manifestations of affective disturbance in sub-Saharan Africa: key themes J Affect Disord 102(1-3) 191-198 https://doi.org/10.1016/j.jad.2006.09.029

52. Hamad R, Fernald LC, and Karlan DS, et al (2008) Social and economic correlates of depressive symptoms and perceived stress in South African adults J Epidemiol Community Health 62(6) 538-544 https://doi.org/10.1136/jech.2007.066191 PMID: 18477753

53. Pirl WF, Greer JA, and Traeger L, et al (2012) Depression and survival in metastatic non-small-cell lung cancer: effects of early palliative care J Clin Oncol 30(12) 1310-1315 https://doi.org/10.1200/JCO.2011.38.3166 PMID: 22430269 PMCID: 3341144

54. South African National Department of Health (2017) National Policy Framework and Strategy on Palliative Care 2017-2022 [http://www. health.gov.za/index.php/2014-08-15-12-53-24/category/460-policy-and-guidelines-2018] 